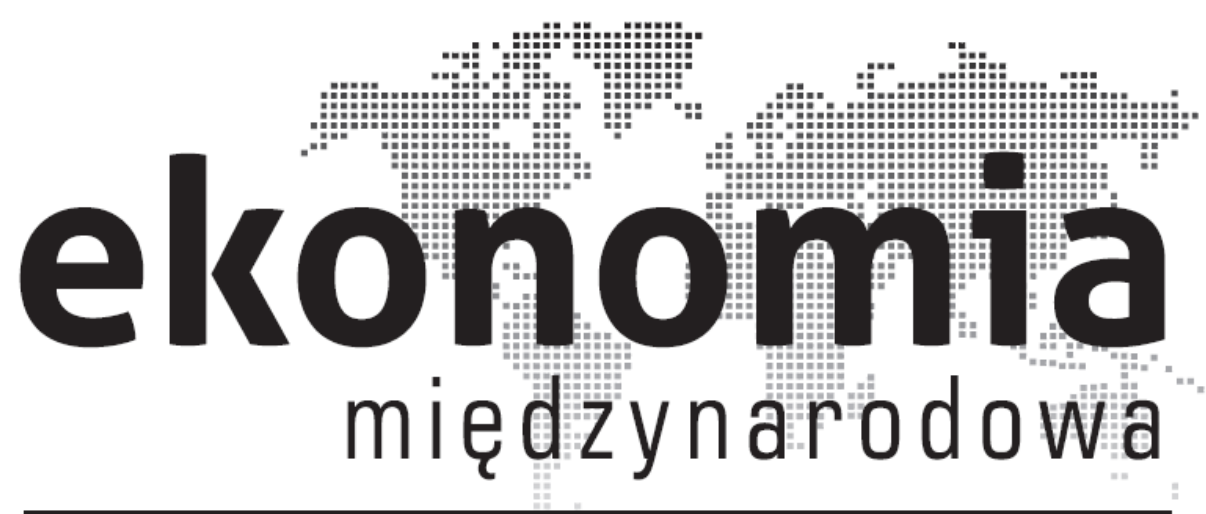

Ekonomia Międzynarodowa

$\mathrm{Nr} 13$ (2016)

Wydawca: Uniwersytet Łódzki

(Publisher: University of Lodz)

www.ekonomia-m.pl

ISSN: 2082-4440 - wydanie papierowe (paper edition)

ISSN: 2300-6005 - wydanie elektroniczne (electronic edition)

Wersja elektroniczna czasopisma jest wersją referencyjną

(Electronic edition is the reference version of the journal)
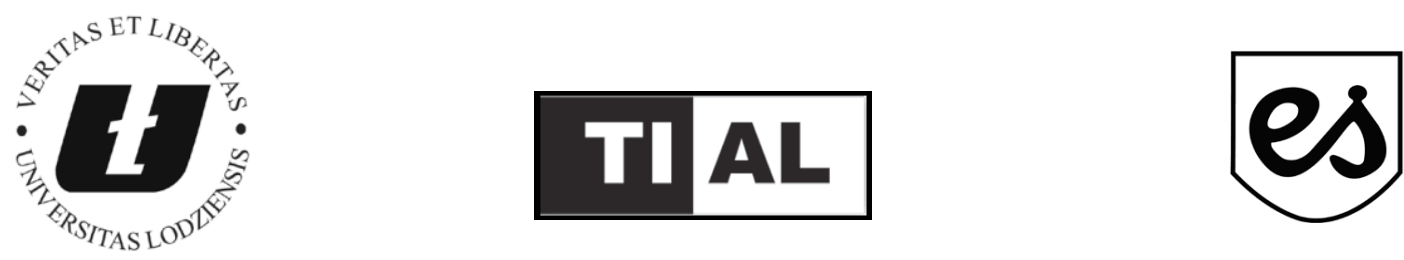


\section{The costs of resource-led development. An analysis of the economic impact of the oil extraction boom in Colombia}

Paulina Kupisz ${ }^{*}$

\section{Introduction}

Oil-exporting countries very often shape their policies around the whole process of the extraction, refining and selling of this natural resource. Even countries with diversified economies are aware of the importance of this source of income for their development and use it as a policy tool in making policy plans. Oil resources are usually used to promote a state's interests and maximize its revenues, which is why exercising control over them is crucial to ensure the support of society. Although there is a tendency to liberalize policies in many sectors of the economy - "that government is best which governs least" - one can observe a high and growing governmental involvement in oil (and gas) extraction plans. This is especially visible in managing foreign direct investments in the sector, where politicians often set up strict rules and are highly demanding towards transnational corporations (TNCs) investing in the country. What is interesting is that states' objectives in doing business with foreign companies are very often inconsistent with the idea of taking full advantage of their presence on their land and maximizing incomes. This is because there are also some political goals that the governments need to fulfill, such as being able to exercise the most power possible over the resources, giving society the feeling that there is national control over their soil, and distributing resources equally and fairly (for example, taking into account the rights of indigenous people). Finding a balance between those (sometimes) contrary interests might be a key to the success of a government of a resource rich country (Lax 1988).

The objective of this article is to present my latest findings on the economic impact of the oil sector development in Colombia in the $21^{\text {st }}$ century. First, some

\footnotetext{
* Paulina Kupisz - MSc, University of Wroclaw, Faculty of Social Sciences, Institute of International Studies.
} 
general, theoretical reflections about the connection between states and oil are presented. Secondly, a short history of oil extraction in Colombia is demonstrated. The third part focuses on describing oil sector management in the country, together with an analysis of the economic consequences of oil-extraction policies introduced in the first decade of the $21^{\text {st }}$ century in Colombia, to face an exploitation boom. The last part is a conclusion.

\section{States and oil: the effects of oil-led development}

In many countries, the development of the natural resource sector is followed by various dilemmas related to the management of the revenues. There are many differences in natural resource governance between states, especially regarding developed and developing countries. In developing ones, precious minerals are used as a fundamental part of national economic plans, a significant part of GDP and (one of) the most important export goods. Lax calls them the lifeline of the national economy, referring especially to the members of OPEC, and indicates a possibility that a lack of these resources would lead those countries to poverty (Lax 1988, p. 106). In any case, the governments need to make a decision about the ownership of the companies in the sector, especially if they used to be fully state-run. The question is whether to leave them public or privatize them, and if so, to what extent. Another question refers to the spending of oil revenues - what part of them should be invested in social policies and fiscal reductions? The geographical distribution of wealth might also prove to be a difficulty: on the one hand, the oil-producing regions are those that possibly need more support, but on the other, the oil wealth remains under national ownership, a fact that may suggest a need for its more equal distribution (Humphreys et al. 2007).

Although the objective of this article is to analyze the practical costs of the oil-led development of a country, it is crucial to mention the existence of a two-fold theoretical vision on natural resources management. The first theory, which is considered mainstream nowadays, is the one initiated by Jevons in 1865 and developed by Gray (1913) and Hotelling (1931), which is the objectivist and neoclassical state-intervention paradigm. It is based on the quite pessimistic conception of the fixity/depletionism of mineral resources, inconsistent with liberal, entrepreneurship ideas. As Bradley reminds us, A.C. Pigou, an English economist and strong advocate of the welfare economy, spoke for many others when he said: "It is the clear duty of Government, which is the trustee for unborn generations as well as for its present citizens, to watch over, and if need be, by legislative enactment to defend, the exhaustible natural resources of the country from rash and reckless despoliation" (Bradley, 2007, p. 70). The theory of state intervention was broadly criticized by economists such as von Mises, Hayek and Rothbard. Although they remained in contemporaneous discourse of the exhaustibility of 
natural resources, they pointed toward refusing governmental involvement in making resource availability plans. Von Mises, for example, stated that overexploitation of mineral resource derives from loopholes in the system, an absence of full private property rights and institutional barriers that prohibit many entrepreneurial activities (Bradley 2007). The work of Erich Zimmermann, from the institutional school of economics, added the important term of "resourceship" to the contemporaneously known theories, in the same way rejecting the "fixity paradigm" and employing the functional factor since, as he stated, the idea of resources is functional, inseparably linked to human wants and human capabilities. As he indicated in his book "World resources and industries": resources are not, they become; they evolve out of the triune interaction of nature, man, and culture, in which nature sets outer limits, but man and culture are largely responsible for the portion of physical totality that is made available for human use... The problem of resource adequacy for the ages to come will involve wisdom more than limits set by nature (Bradley 2007, p. 77). According to Zimmerman, there were many factors, such as culture, laws and governmental policies, which meant that natural resources were considered dynamic - "they become, not are". Considering knowledge to be the greatest human resource, he opted for its predominance over limits set by nature. As already mentioned, although analyzing various natural resource theories is not the subject of this article, it is important to highlight that understanding the briefly described specific contributions made by Austrian economists is vital when analyzing the mineral resource policy of countries, because they may offer new insights into mainstream theories.

\section{Resource curse}

One of the most important topics in analyses of the costs of resource-led development is the phenomenon of the resource curse. In broad terms, it describes how resource-rich countries lack the ability to take advantage of their natural assets. According to Soros (Humphreys et al. 2007), the phenomenon can be divided into three phases. The first of them is the Dutch disease effect, which includes the appreciation of the real exchange rate, which negatively influences other sectors of the economy. The second process concerns the troublesome effect of the fluctuation in commodity prices, and the third is the negative influence of the resource abundance on the political environment.

The resource curse, also called the 'paradox of plenty' theory, pays attention to the fact that those countries that discovered valuable natural resources on their territory very often show worse economic development than countries that were not endowed with them. They often also perform worse in political terms, suffering from various kinds of bad governance, such as corruption, weak democracy, civil wars and other political failures. The term 'resource curse' often refers to a positive relationship between the value of natural resources and civil conflict. 
Ironically, many resource-rich countries yielded economic crises and were not able to achieve and maintain sustainable economic growth. Resource abundance turned out to be a barrier to self-sustaining development, which was not the case regarding the lack of resource endowments. As Humphreys et al. (2007) say, countries such as the Asian Tigers accomplished spectacular economic growth without being resource-abundant. Nevertheless, a great variation occurs between countries with a large resource base, such as the cases of Botswana and Sierra Leone, where the first one, with large diamonds endowments, achieved an average of $7 \%$ economic growth over the past 20 years, and the second, also diamond-abundant, lost 37\% of its GDP per capita from 1971 till 1989. Also, when analyzing documents such as United Nations' Human Development Report, together with the Human Development Index, one can notice a great disparity between resource-abundant countries, such as in the cases of relatively high-ranked Norway or Qatar on the one extreme, and the Republic of Congo and Chad on the other. These countries very often also suffer from rising inequality. (Humphreys et al. 2007).

Apart from the nature of the precious resources themselves, there are also other, external reasons for the resource curse. One of them is the strong bargaining position of the private actors in the sector. Especially in the case of oil and gas, when exploration is capital and technologically intensive, the companies very often own more expertise and knowledge about the resource, which, particularly in the situation where there is little competition, may turn out unfavorably for a country. The aforementioned Dutch disease effect, a sudden increase of a natural resource export and its result - currency appreciation - is another factor that contributes to the resource curse, making non-natural resource goods less competitive on the international market (the 'spending effect'). This effect already had occurred in Colombia in the 1970s in the context of coffee. A shift to international manufacturers, as well as the 'resource pull effect' (a shift of labour and materials to the natural resource sector), produces consequences such as an increased cost for companies in the remaining sectors, or, for example, an increase in inequality, if returns to export sectors such as agriculture or manufacturing are more equitably distributed than returns to the natural resource sector (...) (Humphreys et al. 2007 , p. 6). Another problem is the volatility of income from natural resources, which has three origins: the variation over time in rates of extraction (depending on production peaks and troughs), the variability in the timing of payments by corporations to states (which depends greatly on the nature of agreements between the government and the producing companies), and fluctuations in the value of the natural resources produced (Humphreys et al. 2007, p. 6), so basically the changing world oil and gas prices. These factors result in problems with long-term planning, which is always burdened with uncertainty over financing.

In general, the importance of studying the resource curse is that provides support to the economies of 'cursed countries' to develop in sustainable manner, for the benefit of different sectors of their economies. Nevertheless, there are few 
countries in the world where the resource curse has appeared in the full meaning of this expression. Many countries face specific symptoms of this phenomenon, which at times can lead to the more advanced phase of the resource curse, but very often it 'just' affects a country's economy in a negative way and that is sufficient to provoke some fundamental changes in the policy. This article's objective is to investigate some existent and potential negative economic consequences that stem from the oil abundance and its management in Colombia. In the next part of this article some historical background of Colombian extraction industry will be described, focusing especially on the country's management models.

\section{Historical view on oil extraction in Colombia}

The abundance of oil and gas seems to be a source of 'easy income' that endows the country with a perspective of great welfare for its habitants. Nevertheless, there are many conditions determining the performance of this highly volatile sector and there are almost always strict rules behind every success in this matter. Respect for human rights, non-rent seeking behavior of the main actors, and appropriate, countercyclical macroeconomic policies (fiscal and monetary) in the sector are only some of them. In Colombia, with the exception of some special cases, soil and subsoil are owned by the State, not the owner. The history of State oil extraction management began in 1886, with the Political Constitution. Article 202 established that the State is the owner of the subsoil and non-renewable natural resources, obliging its operators to pay royalties. In 1903, Law 30 arranged issues connected with fiscal burdens and mines, especially in terms of taxes over natural resources, such as platinum, gold and silver, introducing concessions or an annual tax. The concessions over oil were introduced in 1905 with Law 6 and previous legislation from 1873 about carbon mines, which had established that only Congress was able to validate a contract undertaken in order to dispose of or grant the exploitation of coal mines and oil (López et al. 2010).

As López et al. (2010) state, it was only in 1912 when the particular oil legislation was introduced, with Law 110, saying that temporal concessions first need Congress's authorization. Oil production began to gain more importance, which resulted in an increasingly advanced oil legislation. One of the most important issues was defining what hydrocarbons are and what rules and taxes refer to their exploitation. The oil and pipeline construction industry was described as a public utility. Law 120 from 1928 and Law 37 from 1931 introduced the terms of property of land and subsoil and a division between national and particular ownership of oil. The first one was supposed to generate royalties for the nation, and the second one taxes. Both were based on the exploitation of the gross product based on the distance from the sea, another rule announced previously, in 1919. After some advances on the definition making and concession giving process in 1936 (Law 18), 
the Law 160 was introduced in 1952 and the Law 10 in 1961 (a modification of the first one). The last one established better conditions for the state in terms of contracts, for example the reduction of the exploratory phase, and increased government involvement in the production process (López et al. 2010)

Concession contracts were established in the late $19^{\text {th }}$ century. They supposed that the concessionary was charged for all the costs and investments, and additionally was obliged to pay royalties of $11 \%$ of the production value to the State. According to the conditions, they were in force for 50 years, after which all the goods and installations were passed to the State. As a result of this rule, one of the most important steps in Colombian oil history was made: the creation of Ecopetrol - Empresa Colombiana de Petróleos, the Colombian Petroleum Company. It was established in 1951, and in 1969 the Colombian Government changed the existing concession regime for the so called association contracts, with a renewable term of 27 years, production distribution of $20 \%$ royalties, $40 \%$ associate, and $40 \%$ Ecopetrol, and an agreement of a joint contract management between the Associated and Ecopetrol. The contracts let Ecopetrol participate in operations after a discovery had been deemed commercial, and contribute $50 \%$ to the development investments (defined by Law 20).

However, despite the successful exploration activities at first (discoveries of giant oil fields in the $80 \mathrm{~s}$ and at the beginning of the $90 \mathrm{~s}$ ), a variety of factors suddenly appeared in the early 90s. That provoked a decline in production levels and, understandably, investments. According to the Colombian Association of Oil Engineers (Asociación Colombiana de Ingenieros de Petróleo, ACIPET), and the Latin American Oil Industry Association (Asociación Latinoamericana de la Industria del Petróleo, ALIP), those were especially the politics of tiered royalties, related to production levels, the so called ' $\mathrm{R}$ factor' ${ }^{\text {' }}$ and the lack of new finds in terms of oil deposits. The Colombian hydrocarbon sector was close to collapse, especially due to the lack of interest of private, foreign companies in sharing profits after assuming such a risk and in such an unstable security conditions (growing guerilla and paramilitary attacks on oil infrastructure and extortions from kidnapping oil sector employees). Government liabilities increased after the new Constitution in 1991, which pushed the responsibility for pensions, healthcare system and education from local institutions to central government. That produced a debt problem, which the government wanted to fix with oil royalties. These reasons led to Decree 1760 in 2003, which created the National Hydrocarbon Agency (ANH, Agencia Nacional de Hidrocarburos) in 2004 and converted Ecopetrol into a state trading enterprise dedicated to the exclusive integrated activities of the oil indu-

\footnotetext{
${ }^{1}$ An R-factor is the ratio of cumulative receipts from the sale of petroleum to cumulative expenditures. This ratio is initially zero during exploration [since] there is no sale of petroleum -while there may be considerable expenses- and gradually grows in time. An R-factor less than 1 would mean that costs have not been fully recovered yet: total expenditures exceed total receipts. The larger the $R$-factor, the more profitable the operation. The royalty rate or the government's share of production may increase with increasing R-factor (World Bank 2007, p. 1).
} 
stry (exploration, drilling, production, transportation, refining and marketing), allowing it to compete on equal terms with other energy companies (ACIPET/ ALIP, own translation). This step was similar to the Brazilian energy policy towards its national oil company, Petrobras, and the changes that took place in 1997, when the National Petroleum Agency (ANP, Agencia Nacional do Petroleo) was created, a regulatory, monitoring and contracting agency, and the Conselho Nacional de Politica Energética (CNPE), an advisory branch, both created to unburden Petrobras at the upstream and midstream level ${ }^{2}$. The objective of the Colombian government was to foster private investment to increase production and reserves by denationalizing the oil and gas industry. The new policy (dividing the oil sector into a regulating, administrative entity and an oil company) was based on the following conditions: ANH's task was promoting petroleum exploration, drafting and negotiating $E \& P$ agreements, creating attractive conditions for private investment in the sector, and collecting royalty payments (Tordo et al. 2011, p. 6), Ecopetrol on the other hand retained its role as a marketing agent for royalties in kind, which it sold on behalf of the ANH in addition to a large portion of third-party production in Colombia (Tordo et al. 2011, p. 6). At the same time, a new fiscal regime was introduced and some important progress in national security issue took place (especially protecting pipelines from terrorist attacks), which resulted in an increased attractiveness of the country for exploring and producing oil in Latin America. In 2007, Ecopetrol became a joint stock company, which meant it received an investment budget, separate from the national budget of the country and its funds limits. Thanks especially to access to international capital markets, the partially privatized company increased its capital expenditures from $\$ 617$ million in 2004 to almost $\$ 3$ billion in 2008. One of the important questions in terms of growth and development the hydrocarbon sector was fuel price subsidies. As the World Bank's experts highlight: Ecopetrol's competition and growth prospects were largely dependent on the Colombian government's ability to address the issue of fuel price subsidies. Up to Through 2007, Ecopetrol provided significant gasoline and diesel price subsidies to domestic consumers, which cost the company about $\$ 10$ billion annually. Law 1151/2007, provided for the government to reimburse Colombian refiners annually for the price subsidies provided. But the government reimbursement of the 2008 fuel subsidy (approximately \$7 billion) provided by Ecopetrol was significantly delayed. (Tordo et al. 2011, p. 6).

In Figure 1, one can observe total oil production in Colombia between 1951 (the creation of Ecopetrol) and 2013. Additionally, there are data for the production of oil from Ecopetrol and the private sector in the years 1951-2008. It is noticeable that after the production peak in 1999 (more than 815 MBls [thousand barrels] per day), an abrupt drop occurred (541.3 MBls per day in 2003), due to

\footnotetext{
${ }^{2}$ Industrial production of oil and gas is divided into three main levels. The upstream level covers exploration and production of the raw material. The midstream level includes the logistics and transport sector. The downstream level is the refining process, sales and distribution.
} 
the already mentioned reasons. However, the amount of oil production has increased continuously since 2008, with more than 549 MBls per day, to 2013, when oil production in Colombia passed 1 million barrels per day.

Figure 1. Total Colombia oil production 1951-2013, Ecopetrol and private oil production 19512008, MBls

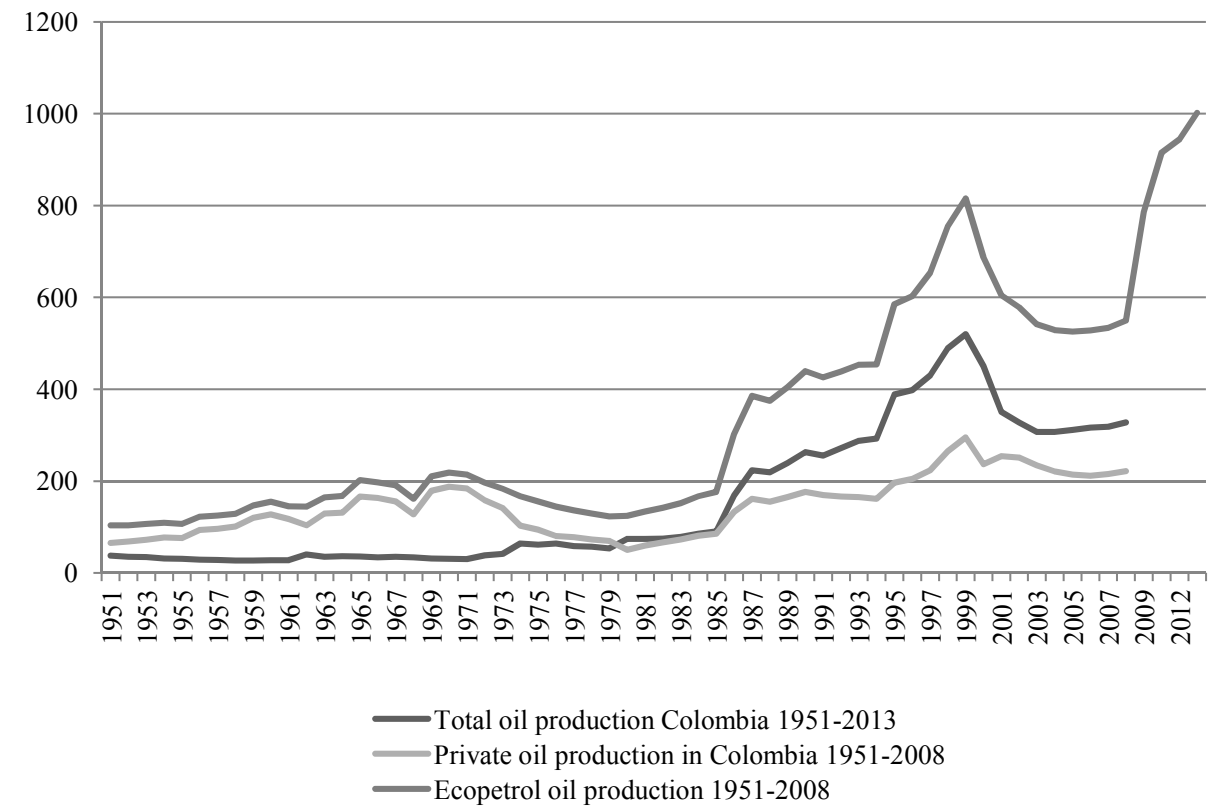

Source: own elaboration based on Sistema de Información de Petróleo y Gas Colombiano.

\section{Oil sector management in Colombia: selected problems and their economic repercussions}

The history of oil exploration and production in Colombia shows the large weight of the reforms introduced in 2003. They had a significant influence on the performance of the oil sector, Ecopetrol as a partially privatized oil company, and the country's economy. First of all, a production boom occurred, and the number of barrels per day (bpd) nearly doubled between 2003 and 2013. Due to the improvements in the investment climate, the country attracted foreign direct investment, as shown in Figure 2 (a dramatic increase from 278 million dollars in 2003 to its peak of 5,471 million dollars in 2012). As Tye (2013) mentions, the influx of foreign capital resulted in a growth of the exploration acreage from 12.5 million hectares in 2003 to 102 million hectares eight years later, which brought important oil recovery technology to the country, and ensured important advances in the transportation infrastructure (though, recently again an object of terrorist attacks). 
Figure 2. Foreign direct investment in Colombia in USD millions, 1994-2014

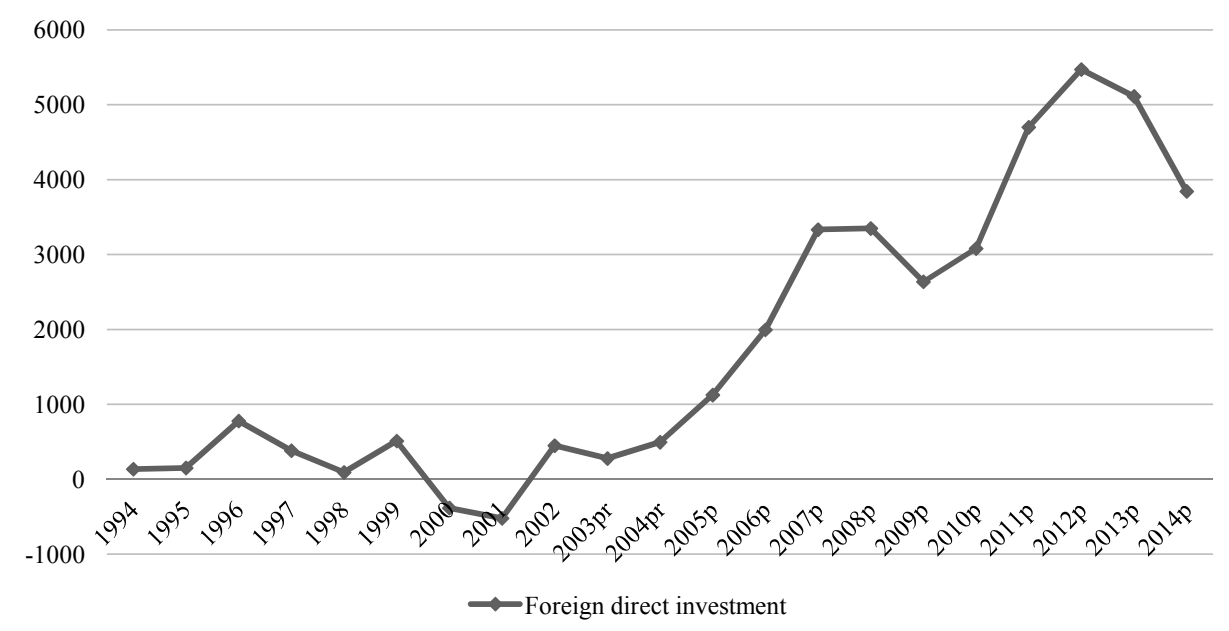

$\mathrm{pr}$ - provisional, $\mathrm{p}$ - preliminary; data for 2014 is till September only

Source: Asociación Colombiana del Petróleo.

As already mentioned, Ecopetrol's situation changed significantly only in 2006, when, according to Law $1118,20 \%$ equity ownership of the company was sold through initial public offering (IPO) in 2007. Since then, Ecopetrol has been present on stock exchanges in four countries: Colombia (Bolsa de Valores de Colombia, BVC), Peru (Bolsa de Valores de Lima, BVL), the United States (the New York Stock Exchange, NYSE), and Canada (the Toronto Stock Exchange, TSX). It is the fourth largest oil company by market capitalization in Latin America, with a value of $\$ 98.25$ billion, overtaking Petrobras in May 2012 (Tye 2013).

Nevertheless, in terms of the country's economy, there are still many challenges for handling Colombia's oil and mining sector. One of them is revenue policy, more specifically the management of taxes and royalties. Their values increased from 5.2 billion dollars in 2009 to 17.7 billion dollars in 2012, but only since 2011, after a constitutional amendment, have they been distributed more equitably among the producing and non-producing departments (Viscidi et al. 2014). Between 1995 and 2010 there was a strong concentration of direct royalties in producing areas, namely, eight departments where $17 \%$ of the country's population is concentrated, and which received $80 \%$ of these royalties. The problem of the General Royalty System (Sistema General de Regalias) before the amendment was especially the fragmentation of projects, non-efficiency in both the planning and execution on the part of the non-producing regions, and, on the other hand, high dependency on the royalties, low sustainable development and low taxation in the producing ones. The new system increased the number of municipalities receiving royalties for investments from 522 in 2011 to 1089 in 2012 (Cárdenas 
2013). However, as Lisa Viscidi, the director of the Energy, Climate Change and Extractive Industries Program at the Inter-American Dialogue points out, the reforms, instead of making income distribution more efficient and giving more control over revenues to the central government to eradicate corruption, brought some unexpected problems. First of all, the producing departments became a victim of a sudden revenue loss, when their share decreased from $74 \%$ to $9.5 \%$ in 2015 , which disturbed the carrying out of projects in such important sectors as health and education. At the same time, it turned out that the non-producing regions were not prepared to receive an additional source of income and efficiently use it. Problems surged with local corruption as well, something that still has not been dealt with by the government. Additionally, there exists a risk that the producing departments might start to put more and more pressure on the central authorities to give them back their rights by, for example, boycotting (or not supporting) oil and mining projects on their land (Viscidi 2014).

Another serious problem of the Colombian petroleum sector that may influence the performance of the country's economy seems to be the investment plans of the oil companies operating on the Colombian land. A survey carried out by the Colombian Oil Association (Asociación Colombiana del Petróleo, ACP) on 37 oil companies, which represent $96 \%$ of the oil production in Colombia, showed some important tendencies that might endanger the country's oil sector performance in the near future. The survey was carried out in October and November 2014, so before the first debate on the wealth tax reform and before the abrupt fall in oil prices. It demonstrated, however, a decreasing tendency in exploration plans and caution in terms of production plans and transport. At the exploration level, about $47 \%$ of the companies had a reduction and $3 \%$ cancelled plans. The main reasons acknowledged by the enterprises for the ideas of dropping investment were environment problems (41\%) and, more importantly $(52 \%)$ economic problems such as: the fall in oil price, tax reform and fewer investment opportunities. Economic problems were also the first reason (indicated by $67 \%$ of the responders) for the production level plans. In comparison with 2013, in 2014 more companies were ready to displace their investment to another country, Mexico being the first competitor, followed by the United States, Brazil, Peru, Argentina and Canada. The main factors responsible for the potential displacement decisions would be lower prospectivity (50\%), difficulties for operating (43\%) and fiscal regulations (income tax, government take - 36\%) (ACP 2014).

According to the ACP's report, the oil sector is the one with major GDP growth in 2008-2012, providing possibilities for other important sectors, such as construction, and it was responsible for accomplishing a large part of the fiscal goals. Nevertheless, it faces many challenges to fully progress and be able to attract more investment, together with maintaining the existing investments. Apart from some specific aspects, such as fiscal incentives for offshore exploration, there 
are problems with stable and clear rules, as well as various operating difficulties. Some examples are shown in Table 1.

Table 1. Challenges for the Colombian government in order to ensure stable and clear rules and eradicate operating difficulties

\begin{tabular}{|l|l|}
\hline Stable and clear rules & Operating difficulties \\
\hline - stable taxation & - expenditure on licenses and consultations \\
- stable contract conditions & - prevent attacks and blockages \\
- clarity in the application of norms & - timely prosecution \\
- control of the new environmental restrictions & - redistribution of royalties \\
\hline
\end{tabular}

Source: ACP 2014, p. 10.

In general, according to the Report, the Colombian Oil Association indicates three main causes for the investment drop: operating difficulties (costs), tax reform (a disincentive) and falling oil prices. The mentioned tax reform may refer especially to the governmental plans of funding social programmes by legislating Law 1739, which took effect in January 2015. The reform changed the rules of personal and corporate taxation by introducing a new form of a wealth tax for individuals or companies with liquid resources exceeding 1,000 million pesos in gross assets, increasing complementary taxes (i.e. CREE, 'income tax for equity') and maintaining tax on financial transactions (Gravamen a los Movimientos Financieros, GMF). According to Article 76, the resources raised thanks to the reform will finance subsidies for a partial covering of the costs of public services such as electric energy and gas for domestic use in the $1^{\text {st }}$ and $2^{\text {nd }}$ socio-economic strata (the so called estratos socioeconómicos in Spanish, i.e. the poorest social groups) (Law 1739). These charges create new burdens for various industries, however, the hydrocarbon sector (especially exploration and production) is one of the most vulnerable to changes due to the high regional potential of new oil discoveries and competing policies of various Latin American countries to attract new investment. In such a competitive environment, every sign of legal instability may be the reason for a displacement of operation activities.

The other reason for cautiousness in introducing new fiscal burdens may be falling oil prices ${ }^{3}$, which can be compensated with growing oil production that depends strongly on the fiscal and political stability of a country. According to the calculations in a Report launched by the United Nations Development Program, if the fall in oil prices to 60 dollars per barrel happens in 2015, the GDP growth value, estimated in 2014 at $4.3 \%$, will stand at $1.4 \%$ annually in 2015 . By 2021, i.e. over the course of seven years, the reduced oil price would result in a $13 \%$ loss of accumulated GDP. Additionally, the repercussions will be observable especially

\footnotetext{
${ }^{3}$ In the time of writing this article, price per barrel stands at 49.67 dollars (WTI classification), according to Bloomberg
} 
at the sectorial level, with mining and construction being the most affected industries. Due to the high dependence on oil exports in Colombia, the country may suffer from increasing unemployment and poverty levels, as well as the contraction of the middle class. For example, it is estimated that the poverty levels would grow from the current $29 \%$ to $31 \%$ in 2010 , which means that six years of fighting this phenomenon would be lost. The dependence may also result in a decreasing level of investment in the country, especially that foreign direct investment in the energy sector during last few years represented around 35\% of the total. One of the important challenges for the country is also fighting exchange rate volatility, which affects trade and may delay the recession. There is a possibility of the overshooting phenomenon occurring, which means that the exchange rate is more volatile than expected (devaluation in excess of the long-run equilibrium level). Other possible dangers could be, for example, a decline in public investment due to the fiscal adjustments (UNDP 2014).

Last but not least, there has been an ongoing discussion about the possibility of the Dutch disease and resource curse occurrence in the country. The report made by Perry and Olivera (2009) reveals that (...) oil and coal production in recent decades has generally had a positive and significant impact on the level of development (measured in GDP per capita) in the municipalities in which these 51 operations are located. For the departments, there is a positive effect of the coal production on economic growth, but, in contrast, a negative effect on hydrocarbon production. Also, the royalties seem to have a positive impact on the level of development of the municipalities that receive them, but a negative one in the case of the departments. (Perry and Oliveira 2009, p. 50-51, own translation)

Those phenomena are possibly related to the 'resource curse' effect, which seems to be confirmed by case studies of the departments such as Arauca, Casnare and Guajira, where the weak economic activity and poor institutionalism were additionally challenged by the oil boom. The result of those phenomena existing concurrently was corruption, rent-seeking behaviour and inefficient use of royalties. In terms of the last problem, and royalty incomes in general, it was revealed that they have a positive impact on the municipalities, increasing public investment levels, but a negative influence on the departments in the same terms (the phenomenon is not explained by the Authors though). The aforementioned departments deal with the problem of low public savings and low tax effort and although their performance in education or health is high, the results are still "not robust". The overall evaluation in 2009 shows that there was some evidence of the natural resource 'curse' in the very abundant and oil-dependent (and in one case oil and coal-dependent) departments, especially in the cases when the oil /mining boom came at an early stage of a weak institutional development and other economic activities (Perry and Oliveira 2009, p. 53, own translation). On the other hand, the Authors notice that the case of the municipalities shows that the oil and mining sector performance possibly contributed to a higher development in gene- 
ral. Among other things, they draw attention to the positive influence of the high institutional quality at the growth and income level (Perry and Oliveira 2009).

However, as noticed in 2013 by Carlos Gustavo Cano, co-director of the Bank of the Republic of Colombia, there might be a ghost of Dutch disease in Colombia. The boom in the energy sector is slowly losing its impetus, existing simultaneously with increasing deficit in the commercial balance of the industrial sector and an equilibrium in the agricultural one, with a strong decrease of the involvement in world coffee production (a 10\% drop in 20 years). The industry plummeted in 2012, by $6 \%$. At the same time, a rapid growth of imports of commodities occurred, $12 \%$ in 2012 , which is two times more that the value of total imports. The growth of the annual internal demand is weakening, revealing a tendency to substitute national goods with imported ones. Between 2004 and March 2013, the Colombian currency, the peso colombiano, appreciated by $37 \%$, much more than in Chile or Peru, i.e. countries that increased their productivity more than Colombia. This results in lower national production of goods and tradable services. Although in 2012 the Colombian peso was the most appreciated currency in the region, the intervention of the Bank of the Republic resulted in depreciation at the end of 2012, however, as it is presented by Cano, its impact seems insufficient. There was the additional risk of the 'voracity effect', which means increased public spending in the time of bonanza. This pro-cyclical policy may result in the decreasing activity of non-oil, tradable sectors, such as agriculture and industry, jeopardizing employment. (Cano 2013).

\section{Conclusion}

Exercising control over natural resources often creates various dilemmas connected with their efficient management. Colombia found itself in a situation when, after a short-lasting euphoria related to the influx of new foreign direct investment to the energy sector, together with a spectacular increase in the production level, it is forced deal with several economic consequences of the management of the oil-sector and some external factors, such as falling world oil prices. Some negative effects are already visible. Those are, for example, withdrawal plans of foreign investors related to, among others, the unstable fiscal environment; problems with equal distribution of oil revenues; and some symptoms of the Dutch disease. Additionally, the competitive Latin American environment means that every policy needs to be analysed from the point of view of the possibility of business displacement to another oil-rich country, such as Mexico, Brazil or Argentina. The government needs to find a balance between accomplishing the goal of funding social programmes, introducing stable and trustworthy policies for the investors in the hydrocarbon industry and projecting its sustainable development. Nevertheless, the authorities of every country are often unprepared for abrupt changes in the 
oil environment, which can destroy many years of building public and investors' trust. This fact creates another big challenge for the current and forthcoming Colombian governments.

\section{Bibliography}

ACIPET/ALIP, Historia del Petróleo en Colombia, Asociación Latinoamericana de la Industria del Petróleo, Bogota, www.alip.org/docs/Historias/breve_historia_petrolera_colombia.pdf.pdf.

ACP, Asociación Colombiana del Petróleo (2014, December), Balance de 2014 $y$ perspectivas de inversión 2015, Bogota, www.acp.com.co/images/home/ noticias/industria_hidrocarburos_comprometida_colombia/encuesta_ambiente inversion.pdf.

Asociación Colombiana del Petróleo, www.acp.com.co.

Bloomberg Business, Energy prices, www.bloomberg.com/energy.

Bradley Jr. Robert L. "Resourceship: An Austrian theory of mineral resources", The Review of Austrian Economics, March 2007, Vol. 20, Issue 1, pp 63-90. http://instituteforenergyresearch.org/media/pdf/1.pdf.

Cano C.G. (2013), La enfermedad holandesa en Colombia: síntomas, causas $y$ tratamiento, presentation made during ANALDEX: II Encuentro logístico e industrial del Caribe, Santa Marta, www.banrep.gov.co/sites/default/files/ publicaciones/archivos/cgc_may_2013_4.pdf.

Cárdenas M. (2013), Colombia: reforma al sistema general de regalías, Ministerio de Hacienda y Crédito Público, Bogota, www.irc.gov.co/irc/es/publicacionesespecialesaudio/ppt\%20reforma $\% 20 \mathrm{al} \% 20$ sistema $\% 20$ gral $\% 20$ de\%20regalias.pdf.

Humphreys M., Sachs J.D., Stiglitz J.E. (2007), Escaping the Resource Curse, Columbia University Press, New York.

Law 1739, December 23, 2014, Ministry of Finance and Public Credit, Republic of Colombia, Bogota, http://wp.presidencia.gov.co/sitios/normativa/leyes/ Documents/LEY\%201739\%20DEL\%2023\%20DE\%20DICIEMBRE\%20 DE\%202014.pdf.

Lax, H. L. (1988). States and Companies: Political Risks in the International Oil Industry, Praeger, New York.

López E., Montes E., Garavito A., Collazos M.M. (2012), La economía petrolera en Colombia (Parte I). Marco legal - contractual y principales eslabones de la cadena de producción (1920-2010), Borradores de Economía, Banco de la República, Bogota, No. 692.

Perry, G., Oliveira, M. (2009). El impacto del petróleo y la minería en el desarrollo regional y local en Colombia, Working Papers, CAF Banco de Desarrollo de América Latina, Caracas, No. 2009/06, www.caf.com/media/3234/200906 
Elimpactodelpetr\%C3\%B3leoylaminer\%C3\%ADa-versi\%C3\%B3nworkingpaperCAF-Ed.MauricioOlivera.pdf.

Sistema de Información de Petróleo y Gas Colombiano, Estadísticas, www.sipg. gov.co.

Tordo S., Tracy B.S., Arfaa N. (2011), National Oil Companies and Value Creation, World Bank Working Paper, The World Bank, Washington, No. 218.

Tye A. (2013), The Rebirth of the Colombian Oil Industry, Perspectives on Business and Economics, Lehigh University, Bethlehem, No. 31.

UNDP (2014), Colombia frente a una destorcida en los precios del petróleo, Cuadernos PNUD.

Viscidi L., Ramírez J.M., Mejía Vergnaud A. (2014, July 3), How Should Colombia Handle Oil and Mining Revenues? Latin American Advisor, InterAmerican Dialogue, Washington, http://thedialogue.org/page.cfm?pageID $=3$ $2 \&$ pubID $=3635 \& s=$ colombia.

World Bank (2007), Contracts for Petroleum Development - Part 2, No. 8 Petroleum Sector Briefing Note, No. 8, www.siteresources.worldbank.org/INTOGMC/Resources/cambodia_oil_gas_newsletter_8.pdf.

\section{Summary}

Oil-rich countries often face negative consequences of natural resources-led development on their overall economic performance. One of the reasons is that a country's rising extraction rates frequently lead to various changes in its public policy and revenue management. Colombia has spectacularly increased its oil production by almost 500,000 barrels per day (bpd) in ten years, which was the effect principally of the implementation of strongly market-oriented petroleum policies in 2003. It is now the fourth largest crude producer in Latin America, registering nearly ten times more export sales than at the end of the $20^{\text {th }}$ century. The economic effects of the oil-boom are already visible, which has created many new challenges the government must face in order to ensure sustainable development in the country, and to be able to mitigate the impact of the recently dropping world oil prices. The purpose of the article is to present the latest findings on the impact of the oil sector development on the Colombian economy in the $21^{\text {st }}$ century, focusing especially on the current situation.

Keywords: Colombia, mineral resources, Dutch disease, oil, development, national oil companies, Ecopetrol 


\section{Streszczenie}

Koszty rozwoju opartego na surowcach naturalnych. Analiza gospodarczych konsekwencji boomu w wydobyciu ropy naftowej w Kolumbii

Państwa bogate w zasoby ropy naftowej często muszą się mierzyć z negatywnymi dla ich wydajności gospodarczej konsekwencjami rozwoju opartego na surowcach naturalnych. Jednym z powodów jest fakt, że zwiększenie poziomu wydobycia w danym kraju często prowadzi do różnorakich zmian w jego polityce publicznej i zarządzaniu przychodami. Kolumbia to kraj, który spektakularnie zwiększył produkcję ropy o prawie 500 tysięcy baryłek dziennie w ciągu ostatnich dziesięciu lat. Było to głównie efektem polityki silnie zorientowanej na przyciąganie inwestycji do sektora naftowego. Kraj jest obecnie czwartym co do wielkości producentem ropy w Ameryce Łacińskiej, odnotowując blisko dziesięć razy większe wartości eksportu niż pod koniec XX w. Gospodarcze skutki boomu naftowego są już widoczne, co stwarza wiele nowych wyzwań dla rządu. Konieczne jest szczególnie zapewnienie Kolumbii zrównoważonego rozwoju i ograniczenie wpływu spadających światowych cen ropy naftowej. Celem artykułu jest przedstawienie wyników badań na temat wpływu rozwoju sektora ropy na gospodarkę kolumbijską w XXI w., ze szczególnym uwzględnieniem obecnej sytuacji.

Słowa kluczowe: Kolumbia, surowce mineralne, choroba holenderska, ropa naftowa, rozwój, państwowe przedsiębiorstwa naftowe, Ecopetrol

JEL: O54, Q32, Q33 